Al Qalam: Jurnal Ilmiah Keagamaan dan Kemasyarakatan https://jurnal.stiq-amuntai.ac.id/index.php/al-qalam

P-ISSN: 1907-4174; E-ISSN: 2621-0681

DOI : 10.35931/aq.v16i2. 922

\title{
ETIKA ADMINISTRASI PUBLIK DALAM PENYELENGGARAAN TATA KELOLA DI INDONESIA
}

\author{
Roro Rukmini Widiaswari \\ Dosen, FIA Univ. Achmad Yani Banjarmasin, Kalimantan Selatan, Indonesia \\ widiaswariroro@gmail.com
}

\begin{abstract}
Abstrak
Etika merupakan elemen penting yang menentukan keberhasilan pelaksanaan kegiatan organisasi dan pelaku administrasi publik. Pentingnya penerapan etika administrasi publik dalam birokrasi pemerintahan Indonesia didasarkan pada permasalahan etika yang terjadi, seperti korupsi, kolusi, dan nepotisme. Penelitian ini bertujuan untuk menggambarkan etika administrasi publik dalam penyelenggaraan tata Kelola/birokrasi di Indonesia. Penelitian ini menggunakan metode kualitatif, dimana data primer diperoleh dari observasi, dan data sekunder diperoleh dari media dan studi kepustakaan. Dari penelitian yang telah dilakukan, diketahui bahwa beberapa pejabat pemerintah di Indonesia kurang akuntabel dalam menjalankan tugas, wewenang, dan tanggung jawabnya sehingga birokrasi publik di era reformasi banyak disorot oleh publik dan mendapat kritik. Untuk mengatasi masalah ini, selain menegakkan hukum, pemerintah juga harus membudayakan dan menerapkan etika administrasi publik bagi aparat birokrasinya. Penelitian ini berkontribusi terhadap kajian tentang etika administrasi publik/birokrasi sehingga nantinya bisa membuka ruang diskusi/kritik terhadap penyelenggaraannya di Indonesia. Selain itu juga menjadi celah diskusi bagi penyelenggara birokrasi pemerintahan untuk memangkas habis praktik korupsi, kolusi dan nepotisme.
\end{abstract}

Kata kunci-Etika, Administrasi Publik, Pemerintah, Indonesia, Birokrasi.

\section{PENDAHULUAN}

Dalam beberapa bulan terakhir banyak pemberitaan media kembali mengungkap berbagai kasus korupsi dan penyalahgunaan kekuasaan yang terjadi di birokrasi pemerintahan, lembaga legislatif dan yudikatif. ${ }^{1}$ Kasus penyalahgunaan kekuasaan terbaru terkait dugaan korupsi yang menimpa mantan Ketua Mahkamah Konstitusi dan Gubernur Banten itu. Tidak hanya masalah korupsi tetapi pelanggaran etika berupa penyalahgunaan kekuasaan juga dilakukan oleh Kepala Daerah dalam kasus lain, seperti kasus penutupan bandara oleh aparat kepolisian pamong praja yang diduga dilakukan atas perintah sepihak Bupati Ngada, Nusa Tenggara Timur.

${ }^{1}$ Zaidan Nawawi, "Ethics of Public Administration in The Administration of Governance in Indonesia,” Journal PPS UNISTI 1, no. 1 (2018).

Al Qalam: Jurnal Ilmiah Keagamaan dan Kemasyarakatan Vol. 16, No. 2

Maret - April 2022 
Berbagai kasus terungkap dan diduga merupakan bentuk penyalahgunaan kekuasaan, yang mengindikasikan pengabaian norma etika dalam birokrasi pemerintahan. ${ }^{2}$ Masalah etika dalam administrasi publik menunjukkan kurangnya perhatian atau pengabaian etika dalam praktik penyelenggaraan administrasi publik. Padahal etika merupakan unsur penting yang menentukan keberhasilan pelaksanaan kegiatan organisasi dan pelaku administrasi publik. Pasalnya, nilai moral terkandung dalam seluruh proses kegiatan administrasi publik. ${ }^{3}$

Saat ini, etika kerap menjadi konsep yang sering "menjadi nomor dua" dalam pemerintahan. Etika seolah menjadi sesuatu yang tidak penting dan tidak menarik untuk menjadi wacana di ranah birokrasi pemerintahan. Akibatnya, fenomena penyalahgunaan wewenang merajalela, tidak hanya di pemerintah pusat, bahkan merambah ke daerah. ${ }^{4}$

Konsep nilai moral dan etika dalam administrasi publik dirumuskan untuk diterapkan dalam kehidupan bernegara dan ruang lingkup administrasi yang sebenarnya. Manfaat dari konsepsi etis seperti itu hanya akan terasa jika benar-benar dapat menjadi bagian dari dinamika administrasi modern. ${ }^{5}$ Dalam banyak hal, konsep dan teori filosofis tentang moralitas di bidang administrasi publik juga diturunkan dari praktik administrasi sehari-hari. Oleh karena itu, pembahasan etika administrasi publik tidak berada dalam ruang hampa, harus selalu mencakup pembahasan penerapannya, bagaimana birokrat dan administrator bertindak atau harus bertindak sesuai aturan etika yang ada. ${ }^{6}$

Terkait dengan berbagai permasalahan penyalahgunaan kekuasaan pemerintahan, etika administrasi publik merupakan salah satu bentuk kontrol terhadap aparatur pemerintah dalam melaksanakan apa yang menjadi tugas pokok, fungsi, dan wewenangnya. Ketika administrasi publik menginginkan sikap, tindakan, dan perilakunya dikatakan baik, maka dalam menjalankan tugas pokoknya, fungsi dan wewenangnya harus bertumpu pada etika administrasi publik. Etika administrasi publik selain digunakan sebagai pedoman, acuan, acuan administrasi publik juga dapat digunakan sebagai standar untuk menentukan sikap, perilaku, dan kebijakan menjadi baik atau buruk.

\footnotetext{
${ }^{2}$ Nicholas Henry, "Paradigms of Public Administration," Public Administration and Public Affairs, no. 1776 (2021).

${ }^{3}$ Muhammad Jusuf Kalla dkk., "Public Administration Reform In Indonesia: Why Indonesia Needs to Reform in 1998 ? Political and Economic Background," March (2019).

${ }^{4}$ Sahya Anggara, Ilmu Administrasi Negara: Kajian Konsep, Teori, Dan Fakta Dalam Upaya Menciptakan Good Governance (Bandung: CV Pustaka Setia, 2012).

${ }^{5}$ L. Sachs B. A. Wolfman, "Administrasi Publik Di Indonesia," Journal of Chemical Information and Modeling 53, no. 9 (2013).

${ }^{6}$ Abdul Mahsyar, "Masalah Pelayanan Publik Di Indonesia Dalam Perspektif Administrasi Publik," Otoritas : Jurnal Ilmu Pemerintahan 1, no. 2 (2011).
}

Al Qalam: Jurnal Ilmiah Keagamaan dan Kemasyarakatan Vol. 16, No. 2 Maret - April 2022 
Begitu banyak teori dan konsep yang membahas tentang norma normatif yang ada di kalangan penguasa negara. Demikian pula konsep-konsep seperti keadilan, kedaulatan rakyat, kepentingan umum, norma, dan sebagainya. Namun terkadang deskripsi yang terkandung di dalamnya begitu abstrak sehingga sulit untuk dipahami.

\section{METODE PENELITIAN}

Penelitian ini menggunakan metode kualitatif. Sumber data dalam penelitian ini berasal dari data primer dan data sekunder. ${ }^{7}$ Data primer diperoleh dari observasi terhadap penerapan etika administrasi publik dalam penyelenggaraan pemerintahan di Indonesia. Data sekunder diperoleh dari media dan studi literatur. Data yang diperoleh untuk penelitian sebelumnya divalidasi melalui cross check data dengan teknik triangulasi sumber data. ${ }^{8}$

\section{HASIL DAN PEMBAHASAN}

Etika adalah seperangkat nilai sebagai pedoman, acuan, pedoman apa yang harus dilakukan dalam melaksanakan tugasnya, tetapi juga berfungsi sebagai standar untuk menilai apakah sifat, perilaku, tindakan dalam pelaksanaan tugas dianggap baik atau buruk. Oleh karena itu, dalam etika, ada sesuatu yang bernilai yang dapat memberikan penilaian bahwa sesuatu itu dikatakan baik atau buruk. ${ }^{9}$

Penggunaan istilah etika administrasi publik adalah ambigu. Istilah tersebut dapat berarti ilmu yang membahas tentang prinsip-prinsip etika (moral) yang melandasi tindakan aparat birokrasi pemerintah, terutama dalam menjalankan tugas dan wewenangnya. Selain itu, ada definisi lain, yaitu etika administrasi publik sebagai "seperangkat nilai yang menjadi acuan atau pedoman bagi tindakan manusia dalam organisasi” sebagaimana dikemukakan oleh Darwin. ${ }^{10}$

Mengacu pada pendapat Bertens dan Darwin yang menarik kesimpulan bahwa etika (termasuk etika birokrasi) memiliki dua fungsi. Pertama, sebagai pedoman atau acuan bagi penyelenggara negara (birokrasi publik) dalam menjalankan tugas dan wewenangnya, tindakannya dalam organisasi dinilai baik, terpuji, dan tidak tercela. Kedua, etika birokrasi

\footnotetext{
${ }^{7}$ Raco Jozef, Metode Penelitian Kualitatif: Jenis, Karakteristik Dan Keunggulannya (Jakarta: PT Gramedia Widiasarana Indonesia, 2010).

${ }^{8}$ Cholid Narbuko and Abu Achmadi, Metodologi Penelitian (Jakarta: Bumi Aksara, 2012).

9 Riyadi, "Rekonstruksi Paradigma Administrasi Negara Dan Aplikasinya: Orientasi Pemberdayaan Pemerintahan Daerah," Jurnal Wacana Kinerja 13, no. 2 (November 2010).

${ }_{10}$ Muliati, "Administrasi Negara Dalam Kerangka Sistem Pemerintahan Negara Republik Indonesia," Meraja Journal 2, no. 1 (2019).
}

Al Qalam: Jurnal Ilmiah Keagamaan dan Kemasyarakatan Vol. 16, No. 2 Maret - April 2022 
sebagai standar penilaian, apakah sifat, perilaku, dan tindakan birokrasi publik (Administrasi Publik) dianggap baik, tidak tercela dan terpuji. ${ }^{11}$

Sedangkan menurut Chandler dan Plano etika administrasi publik didefinisikan sebagai berikut: Etika adalah aturan atau standar yang mengatur, perilaku moral anggota suatu organisasi atau profesi manajemen", atau dengan kata lain adalah aturan atau standar manajemen yang menjadi pedoman moral bagi penyelenggara negara dalam menjalankan tugasnya melayani masyarakat. ${ }^{12}$

Dalam ruang lingkup pelayanan publik, etika administrasi publik diartikan sebagai filosofi dan standar profesi (kode etik) atau aturan perilaku yang benar yang harus dipatuhi oleh penyelenggara layanan publik atau administrasi publik. ${ }^{13}$ Dengan demikian dapat disimpulkan bahwa etika administrasi publik adalah aturan atau standar manajemen, arahan moral bagi anggota organisasi atau pekerjaan manajemen; Aturan atau standar manajemen yang menjadi pedoman moral bagi penyelenggara negara dalam menjalankan tugasnya melayani masyarakat. Aturan atau standar dalam etika administrasi negara berkaitan dengan personel, persediaan, keuangan, administrasi, dan hubungan masyarakat. ${ }^{14}$

Pentingnya etika administrasi publik tersebut adalah sebagai berikut. ${ }^{15}$ Pertama, alasan kepentingan umum yang harus dipenuhi oleh pemerintah karena pemerintah memiliki tanggung jawab dalam memberikan pelayanan. Pemerintah diharapkan dapat menjalankan tugasnya secara profesional dan harus mengambil keputusan politik yang tepat tentang siapa mendapat apa, berapa banyak, di mana, kapan, dan sebagainya. Kenyataan menunjukkan bahwa pemerintah tidak memiliki pedoman atau kode etik moral yang memadai. Anggapan bahwa semua aparatur pemerintah adalah mereka yang telah teruji dan selalu membela kepentingan publik atau masyarakat, tidak selalu benar. Banyak kasus membuktikan bahwa kepentingan pribadi, keluarga, kelompok, partai, bahkan struktur yang lebih tinggi mendikte perilaku seorang birokrat atau aparatur pemerintah. Birokrat dalam hal ini tidak memiliki "kemandirian" dalam tindakan etis, atau dengan kata lain tidak ada "otonomi etis". ${ }^{16}$

${ }^{11}$ I Ketut Suardita, "Diktat Ilmu Administrasi Negara," Hukum Administrasi Negara Fakultas Hukum Universitas Udayana, 2016, 1-67.

${ }^{12}$ Ali Mufiz, "Pengantar Ilmu Administrasi Negara," Jakarta: Graha Ilmu, 2016.

${ }^{13}$ Haedar Akib, "Artikulasi Perkembangan Ilmu Administrasi Publik," Jurnal Baca Universitas Pepabri Makassar 3, no. 1 (2009).

${ }^{14}$ Mason C Hoadley, "Modern Indonesian Administration: Collegial, Abdi-Dalem, Rational-, Or Ideological- Bureaucratic?," Jurnal Administrasi Publik 3, no. 1 (2004).

${ }^{15}$ Fajar Tri Sakti, Sistem Administrasi Negara Indonesia (Bandung: Jurusan Administrasi Publik, 2020).

${ }^{16}$ Teguh Kurniawan, "Mewujudkan Good Governance Di Era Otonomi Daerah: Perspektif UU NO. 22 Tahun 1999 Dan UU NO. 32 Tahun 2004," The 1 St Accounting Conference Faculty of Economics Universitas Indonesi, November (2007).

Al Qalam: Jurnal Ilmiah Keagamaan dan Kemasyarakatan Vol. 16, No. 2 Maret - April 2022 
Alasan kedua lebih kepada lingkungan di dalam birokrasi yang memberikan pelayanan itu sendiri. Alasan ketiga menyangkut karakteristik masyarakat yang terkadang begitu variatif sehingga memerlukan perlakuan khusus. Mempekerjakan pegawai negeri dengan menggunakan prinsip "kesesuaian antara orang dan pekerjaannya" merupakan prinsip yang perlu dipertanyakan secara etis karena prinsip itu akan mengakibatkan ketidakadilan, di mana calon yang dipekerjakan hanya berasal dari daerah yang relatif lebih maju.

Alasan keempat adalah kesempatan untuk mengambil tindakan terhadap etika pelayanan publik yang berlaku. Pelayanan publik tidak sesederhana yang dibayangkan, atau dengan kata lain, kompleksitasnya menyangkut nilai pelayanan itu sendiri dan cara penyampaian pelayanan publik itu sendiri. Kompleksitas dan fondasi ini mendorong penyedia layanan publik untuk mengambil langkah-langkah profesional berdasarkan "kebijaksanaan". Dan kebebasan ini seringkali menggiring aparat pemerintah untuk bertindak tidak sesuai dengan kode etik atau pedoman perilaku yang ada.

Aparat birokrasi memiliki kewajiban lebih etis dalam kaitannya dengan perilakunya daripada swasta. Demikian pula, aparat birokrasi tingkat tinggi di lembaga pemerintah memiliki kewajiban etis lebih dari yang lain. Implikasi lebih lanjut dari pendapat tersebut adalah bahwa setiap aparat birokrasi wajib memiliki sikap mental dan perilaku yang mencerminkan keunggulan akhlak, keutamaan, dan berbagai prinsip etika yang bersumber dari keutamaan moral, khususnya keadilan. ${ }^{17}$ Tanpa prinsip-prinsip etika tersebut, aparat birokrasi tidak mungkin mampu memelihara kehidupan suatu bangsa dan menciptakan masyarakat yang damai dan sejahtera. Bahkan sebaliknya, kehidupan orang bisa saja terjerumus ke dalam kecemasan dan kesengsaraan. Oleh karena itu, setiap aparat birokrasi wajib memahami prinsip-prinsip etika yang bersumber dari berbagai kebajikan moral, kemudian memelihara diri agar benar-benar menghayati prinsipprinsip etika tersebut, dan terakhir menerapkannya semaksimal mungkin dalam tindakannya. ${ }^{18}$

Berbagai prinsip etika dalam penyelenggaraan pemerintahan adalah:

a. Tanggung Jawab

Prinsip etika ini menyangkut keinginan aparat birokrasi untuk memikul kewajiban dengan penuh tanggung jawab, dan ikatan yang kuat untuk melaksanakan semua tugas dan pekerjaan secara memuaskan. Aparatur birokrasi harus memiliki keinginan yang besar untuk menjalankan fungsinya secara efektif, utuh, dan paling memuaskan. Akuntabilitas ditujukan kepada masyarakat, lembaga, dan atasan langsungnya. Kecenderungan untuk melepaskan tanggung jawab

\footnotetext{
17 Teguh Kurniawan, "Pergeseran Paradigma Administrasi Publik: Dari Perilaku Model Klasik Dan NPM Ke Good Governance," Jurnal Administrasi Negara 7, no. 23 (2007).

18 Siti Widharetno Mursalim dkk., Kebijakan Publik Dan Transparansi Penyelenggaraan Pemerintahan Daerah, Journal of Chemical Information and Modeling, vol. 2, 2019.
}

Al Qalam: Jurnal Ilmiah Keagamaan dan Kemasyarakatan Vol. 16, No. 2 Maret - April 2022 
atau kesediaan untuk melemparkan tanggung jawab kepada orang lain, atau kebiasaan mengusulkan "hanya mengikuti perintah" harus dihilangkan dari setiap aparat birokrasi yang baik. Setiap aparat birokrasi harus siap memikul tanggung jawab atas apa yang dilakukannya. Mereka tidak boleh terjebak dengan alasan hanya mengikuti instruksi atau melaksanakan kebijakan pemerintah.

b. Dedikasi

Pengabdian adalah keinginan yang keras untuk melaksanakan tugas-tugas pekerjaan dengan segenap tenaga (pikiran dan otot atau mental dan fisik), segenap semangat yang menggebu-gebu, dan penuh dengan perhatian yang tidak mementingkan diri sendiri yang bersifat pribadi seperti ingin dipromosikan atau digabung. Setiap aparat birokrasi dalam pelaksanaan tugasnya harus selalu dan terus menerus menunjukkan keterlibatan diri (involvement of self) dan penuh semangat. Kecenderungan untuk bekerja setengah hati atau asal-asalan seharusnya tidak ada dalam diri aparat birokrasi yang baik. Pengabdian ini diarahkan pada jabatan, keahlian, dan profesinya. ${ }^{19}$

c. Loyal

Asas etik ini adalah kesadaran seorang pejabat untuk taat secara ikhlas terhadap tujuan bangsa, konstitusi negara, peraturan perundang-undangan, lembaga, tugas jabatan, dan atasan demi tercapainya cita-cita bersama. Pelaksanaan tugas rangkap jabatan, pertimbangan untung rugi, atau bahkan dengan kebiasaan sabotase tidak boleh diketahui oleh aparat birokrasi manapun. Jika seorang aparat birokrasi tidak mampu menjalankan tugasnya secara penuh, tidak mau terikat oleh instansinya, atau tidak sesuai dengan kebijaksanaan atasannya, maka tindakan etisnya adalah mengundurkan diri dari jabatannya. ${ }^{20}$

d. Kepekaan

Prinsip etika ini mencerminkan kemauan dan kemampuan aparat birokrasi untuk memperhatikan dan mewaspadai perkembangan baru, perubahan keadaan, dan kebutuhan yang muncul dalam kehidupan masyarakat dari waktu ke waktu dengan upaya terbaik untuk meresponnya. Sikap acuh tak acuh, selama tugas-tugas rutin telah selesai, atau tidak mau susah payah diperbarui, juga harus disingkirkan dari diri sendiri.

e. Kesetaraan

Salah satu kebajikan utama dari badan-badan pemerintah yang ditujukan untuk melayani semua orang dan melayani kebaikan bersama adalah perlakuan yang adil. Perlakuan yang adil biasanya dapat diwujudkan dengan memberikan perlakuan yang sama tanpa diskriminasi atau

${ }^{19}$ Darmanto, "Pengertian Ilmu Administrasi," Paja3210/Modul 1, 2020, 1-48.

${ }^{20}$ Rainer Rohdewohld, Public Administration in Indonesia, 1995, 179.

Al Qalam: Jurnal Ilmiah Keagamaan dan Kemasyarakatan Vol. 16, No. 2 Maret - April 2022 
pilih kasih kepada semua pihak. Maka kesetaraan dalam perlakuan, pelayanan, dan pengabdian harus diberikan oleh setiap aparat birokrasi kepada publik tanpa memandang sanak saudara, ikatan politik, asal keturunan, atau status sosial. Diskriminasi perlakuan yang sewenang-wenang atau pribadi tidak boleh dilakukan oleh aparat birokrasi yang adil. ${ }^{21}$

f. Keadilan

Kesetaraan perlakuan semua pihak sebagai prinsip etika tidak selalu mencapai keadilan dan kewajaran. Isu dan kebutuhan di masyarakat sangat beragam sehingga memerlukan perlakuan yang berbeda asalkan didasarkan pada pertimbangan yang adil atau alasan yang tepat. Jadi, sehubungan dengan kelompok tertentu dan untuk situasi tertentu perlu diperlakukan sama. Tetapi terhadap kelompok lain dan dalam kondisi khusus yang berbeda mungkin diperlukan perlakuan yang tidak setara. Untuk itu yang harus diperhatikan adalah kepatutan. Asas kepatutan mengacu pada suatu hal yang sesuai dengan pertimbangan moral atau etika yang berlaku dalam kehidupan masyarakat. ${ }^{22}$

Seorang aparatur pemerintah yang beretika maka ia akan melakukan tugasnya dengan penuh tanggung jawab, nilai-nilai akuntabilitas dan profesionalisme akan selalu dijaga oleh mereka. Sementara kepercayaan masyarakat terhadap aparatur pemerintah semakin menurun akibat tindakan aparatur pemerintah yang tidak mencerminkan rasa kepedulian dan kepekaan terhadap aspirasi masyarakat, aparatur pemerintah yang baik akan selalu berusaha meningkatkan kinerjanya. Dalam beberapa kasus, studi ini menemukan adanya komitmen yang baik dari beberapa aparatur pemerintah, baik di pusat maupun daerah, untuk menghilangkan budaya korupsi, menanamkan profesionalisme, transparansi, dan akuntabilitas.

Korupsi dapat terjadi kapan saja dan di mana saja selama pertemuan niat dan kesempatan, seperti yang telah ditunjukkan sebelumnya. Korupsi, kolusi, dan nepotisme di Indonesia terjadi pada tingkat birokrasi di tingkat tinggi, menengah, dan rendah. Oleh karena itu, untuk mencegah atau menangani korupsi, pemerintah harus berusaha untuk tidak mempertemukan niat dan peluang korupsi. Salah satu upaya untuk mencegah ketidakadilan keduanya adalah dengan menjunjung tinggi etika birokrasi dalam birokrasi. Nilai-nilai etika birokrasi sebagaimana diuraikan di atas, jika benar-benar sudah menjadi "norma” yang harus diikuti dan dipatuhi bagi birokrasi publik dalam menjalankan tugas dan wewenangnya, maka akan mampu mencegah terjadinya korupsi di tubuh birokrasi publik meskipun ada tidak ada lembaga pengawas sebagaimana tersebut di atas. Namun, etika birokrasi saja tidak cukup untuk memastikan perilaku korupsi tidak dilakukan di birokrasi. Yang terpenting adalah kembali ke kepribadian masing-masing aktor (manusia).

${ }^{21}$ Kridawati Sadhana, Realitas Kebijakan Publik (Malang: UM PRESS, 2011).

22 J. C. Westhoven, "Public Administration: Its Nature and Scope," Australian Journal of Public Administration 1 A, no. 3 (1938).

Al Qalam: Jurnal Ilmiah Keagamaan dan Kemasyarakatan Vol. 16, No. 2 Maret - April 2022 
Dengan kata lain, pengendalian intern berupa keyakinan dan agama yang melekat pada diri manusia.

\section{KESIMPULAN}

Pemerintah pada hakekatnya adalah pelayanan kepada masyarakat. Ia diadakan bukan untuk melayani diri sendiri, tetapi untuk melayani masyarakat dan menciptakan kondisi yang memungkinkan setiap anggota masyarakat mengembangkan kemampuan dan kreativitasnya untuk mencapai tujuan bersama. Paradigma pemerintahan telah bergeser dari paradigma "rule government" menjadi "good governance". Pemerintah yang selalu berpegang pada paradigma "rule government" selalu lebih bertumpu pada peraturan perundang-undangan yang berlaku. Berbeda dengan "good governance", dalam penyelenggaraan pemerintahan, pembangunan dan pelayanan publik tidak semata-mata bertumpu pada pemerintahan atau negara tetapi harus melibatkan seluruh elemen, baik di dalam internal birokrasi maupun di luar birokrasi publik.

Administrasi negara (birokrasi publik) sebagai lembaga negara yang mengemban misi pemenuhan kepentingan publik, bertanggung jawab kepada publik yang dilayaninya. Ada tiga hal penting yang menyangkut pertanggungjawaban penyelenggaraan negara kepada publik yaitu akuntabilitas, responsibilitas, dan daya tanggap.

Namun pada kenyataannya, hanya sedikit pejabat pemerintah yang kurang akuntabel dalam menjalankan tugas, wewenang, dan tanggung jawabnya. Akibatnya, birokrasi publik di era reformasi banyak disorot publik dan mendapat kritik. Fokusnya lebih pada praktik-praktik jahat (mal-administration) etika administrasi publik dalam menjalankan tugas dan tanggung jawabnya. Bentuk maladministrasi dapat berupa korupsi, kolusi, nepotisme, inefisiensi, dan ketidakprofesionalan. Bentuk maladministrasi pada umumnya lebih berkaitan dengan perilaku individu yang menduduki suatu jabatan. Untuk mengatasi masalah ini, selain menegakkan hukum, pemerintah juga harus membudayakan dan menerapkan etika administrasi publik bagi aparat birokrasi.

\section{DAFTAR PUSTAKA}

Akib, Haedar. "Artikulasi Perkembangan Ilmu Administrasi Publik." Jurnal Baca Universitas Pepabri Makassar 3, no. 1 (2009).

Anggara, Sahya. Ilmu Administrasi Negara: Kajian Konsep, Teori, Dan Fakta Dalam Upaya Menciptakan Good Governance. Bandung: CV Pustaka Setia, 2012.

Darmanto. "Pengertian Ilmu Administrasi." Paja3210/Modul 1, 2020, 1-48.

Henry, Nicholas. "Paradigms of Public Administration." Public Administration and Public Affairs, no. 1776 (2021). https://doi.org/10.4324/9781315663067-10.

Al Qalam: Jurnal Ilmiah Keagamaan dan Kemasyarakatan Vol. 16, No. 2

Maret - April 2022 
Hoadley, Mason C. "Modern Indonesian Administration: Collegial, Abdi-Dalem, Rational-, Or Ideological- Bureaucratic?" Jurnal Administrasi Publik 3, no. 1 (2004).

Jozef, Raco. Metode Penelitian Kualitatif: Jenis, Karakteristik Dan Keunggulannya. Jakarta: PT Gramedia Widiasarana Indonesia, 2010.

Kalla, Muhammad Jusuf dkk. "Public Administration Reform In Indonesia: Why Indonesia Needs to Reform in 1998 ? Political and Economic Background," March (2019).

Kurniawan, Teguh. "Mewujudkan Good Governance Di Era Otonomi Daerah: Perspektif UU NO. 22 Tahun 1999 Dan UU NO. 32 Tahun 2004." The 1 St Accounting Conference Faculty of Economics Universitas Indonesi, no. November (2007).

"Pergeseran Paradigma Administrasi Publik: Dari Perilaku Model Klasik Dan NPM Ke Good Governance.” Jurnal Administrasi Negara 7, no. 23 (2007).

Mahsyar, Abdul. "Masalah Pelayanan Publik Di Indonesia Dalam Perspektif Administrasi Publik." Otoritas: Jurnal Ilmu Pemerintahan 1, no. 2 (2011). https://doi.org/10.26618/ojip.v1i2.22.

Mufiz, Ali. "Pengantar Ilmu Administrasi Negara.” Jakarta: Graha Ilmu, 2016.

Muliati. "Administrasi Negara Dalam Kerangka Sistem Pemerintahan Negara Republik Indonesia." Meraja Journal 2, no. 1 (2019).

Mursalim, Siti Widharetno, Abdurrozzaq Hasibuan, oris krianto Sulaiman, Erni Mulyanie, Resti Annisa Husna, Iwan Apriandi, Maiti, dkk. Kebijakan Publik Dan Transparansi Penyelenggaraan Pemerintahan Daerah. Journal of Chemical Information and Modeling. Vol. 2, 2019.

Narbuko, Cholid, dan Abu Achmadi. Metodologi Penelitian. Jakarta: Bumi Aksara, 2012.

Nawawi, Zaidan. "Ethics of Public Administration in The Administration of Governance in Indonesia." Journal PPS UNISTI 1, no. 1 (2018). https://doi.org/10.48093/jiask.v1i1.1.

Riyadi. "Rekonstruksi Paradigma Administrasi Negara Dan Aplikasinya: Orientasi Pemberdayaan Pemerintahan Daerah.” Jurnal Wacana Kinerja 13, no. 2 (November 2010).

Rohdewohld, Rainer. Public Administration in Indonesia, 1995.

Sadhana, Kridawati. Realitas Kebijakan Publik. Malang: UM PRESS, 2011.

Sakti, Fajar Tri. Sistem Administrasi Negara Indonesia. Bandung: Jurusan Administrasi Publik, 2020.

Suardita, I Ketut. "Diktat Ilmu Administrasi Negara." Hukum Administrasi Negara Fakultas Hukum Universitas Udayana, 2016.

Westhoven, J. C. "Public Administration: Its Nature and Scope." Australian Journal of Public Administration 1 A, no. 3 (1938). https://doi.org/10.1111/j.1467-8500.1938.tb02127.x.

Wolfman, L. Sachs B. A. "Administrasi Publik Di Indonesia." Journal of Chemical Information and Modeling 53, no. 9 (2013).

Al Qalam: Jurnal Ilmiah Keagamaan dan Kemasyarakatan Vol. 16, No. 2

Maret - April 2022 